\title{
Cultivation of marine ciliates (Tintinnida) and heterotrophic flagellates*
}

\author{
K. Gold \\ Osborn Laboratories of Marine Sciences; Brooklyn, N.Y., US A
}

KURZFASSUNG: Kultur mariner Ciliaten (Tintinnida) und heterotropher Flagellaten. Folgende heterotrophe Protozoen sind mit Erfolg in Kultur genommen worden: Tintinnopsis beroidea (Tintinnida), Cryptothecodinium cobnii und Noctiluca scintillans (Dinoflagellata), Diaphanoeca grandis und Acanthoecopsis sp. (Choanoflagellata). Angaben über Isolierung, Kulturtechnik und Ernährung sowie einige diese Arten betreffende biologische Daten werden mitgeteilt.

\section{INTRODUCTION}

A challenge to ecologists during the next decade lies in cultivation of a greater variety of marine heterotrophic protozoans than is presently available for study. This group comprises both osmotrophic and holozoic organisms that are markedly affected by the content and quality of organic substances in sea water, and/or the composition of the particulate fraction. Many are known to have high metabolic rates and rapid generation times (PAvLovsKaYA 1969), thus making their roles as grazers and nutrient regenerators worthy of greater consideration. Cultivation of representative species will afford the opportunity to examine their requirements in vitro, as one way to evaluate their impact on the marine environment.

This paper describes the heterotrophic Protozoa that are presently under investigation in this laboratory, and outlines their nutritional status and some potential applications.

\section{MATERIALS AND METHODS}

The heterotrophic species presently under investigation in this laboratory are: Tintinnopsis beroidea (several strains), Cryptothecodinium cobnii, Noctiluca scintillans, Diaphanoeca grandis, and Acanthoecopsis sp. Other species that were cultured and which contributed to an understanding of the Tintinnida were: T. tubulosa (GoLD

* Supported by a contract with the U.S. Atomic Energy Commission, reference number NYO-3658-18. 
1968); T. lohmanni (Gold 1969a); Favella campanula (Gold 1969b) and Metacylis $\mathrm{sp}$.

All of the heterotrophs referred to in this paper were obtained locally with the exception of Cryptotbecodinium cobnii. The usual method for establishing strains was to separate the desired organism from the rest of the plankton by means of finely drawn pipets. Carry-over of some nannoplankton organisms was considered desirable for Tintinnida, since exact food requirements were unknown.

The media routinely used in cultivation are: Tintinnida, medium D (GoLD 1968); Noctiluca and choanoflagellates, medium $D$ enriched with organic substances; $C$. cobnit, medium $\mathrm{A}_{2} \mathrm{E}_{6}$ (GOLD \& BAREN 1966). All of the cultures are kept in $125 \times 20 \mathrm{~mm}$ screw-cap test tubes.

Maintenance temperatures for the different species vary. Tintinnopsis and choanoflagellates prefer $10^{\circ} \mathrm{C}$; Noctiluca grows optimally at $20^{\circ} \mathrm{C}$, and C. cobnit at $30^{\circ} \mathrm{C}$. The latter can be routinely maintained at room temperature.

\section{RESULTS}

Several of the Tintinnida that have been observed locally are shown in Figures 1-9. Figures 1-3 are photographs of tintinnids that were maintained for extended periods but have since died; Figures $4-6$ are aspects of Tintinnopsis platensis, the only ciliate shown here that was not cultured. It is included here, however, to demonstrate that this group may be rather effective in movement of small particles. Note the rod within the body of the ciliate in Figure 5, and the numerous symmetrical fragments cemented to the lorica (Fig. 6). Figures 7 and 8 are of T. beroidea, a strain that was isolated in January, 1969. Figure 7 is a normal individual while an abnormal cell is seen in Figure 8. Both were photographed at the same magnification, and a difference in lorica size is apparent. Note also that the incompletely divided individuals lack a lorica. Figure 9 is of Metacylis sp. Though it lived in vitro a very short time, it was useful for measurement of its generation time.

For each of three of the species of Tintinnida cultured thus far (T. tubulosa, Fig. 1; T. lobmanni, Fig. 2; F. campanula, Fig. 3), there appeared to be 2 growth curves superimposed on each other, detectable only after extended periods in vitro. (1) There was a normal growth curve, often erratic, which typically included a lag period, logarithmic growth, stationary and death phases. (2) There was also a longer period oscillation whereby the strain lost its viability and eventually could not be revived, a characteristic of the ageing process that has been described by MAUPAS for Stylonychia and other infusoria (see for example Kuno 1966). Similar fluctuations have been observed in Foraminifera cultures (LEE et al. 1966) where certain strains have been difficult to establish.

The reasons for the decline in tintinnid viability are unknown, but failure to conjugate was suggested as a possibility (Goun 1969b). This indicated that a change in culture conditions was probably required at some stage in the life cycle. In addition to conjugation as a way to extend longevity, other methods must be con- 
sidered. Decrease in cell size accompanied in vitro cultivation of $F$. campanula (Golp 1969b). This was believed to be due to a more rapid rate of division than would be experienced in nature. In that case, retardation of division, through starvation or lower temperature, may be beneficial at some stage.

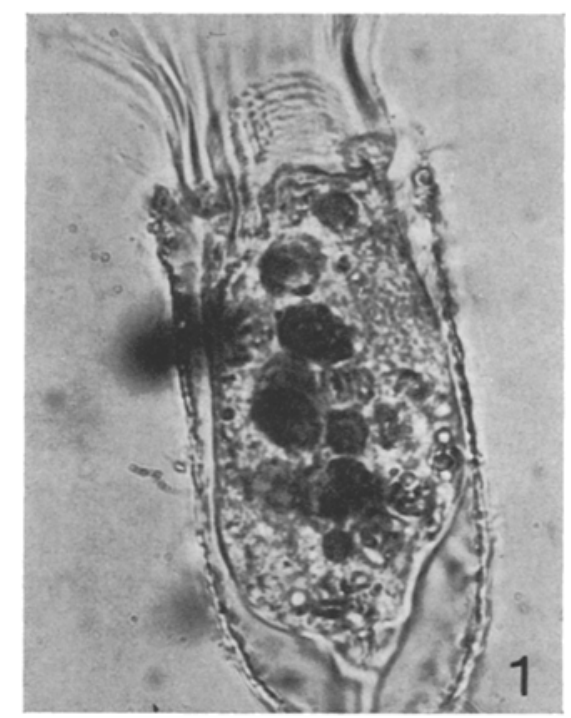

Fig. 1: Tintinnopsis tubulosa. (Cultured, after Gold 1968)
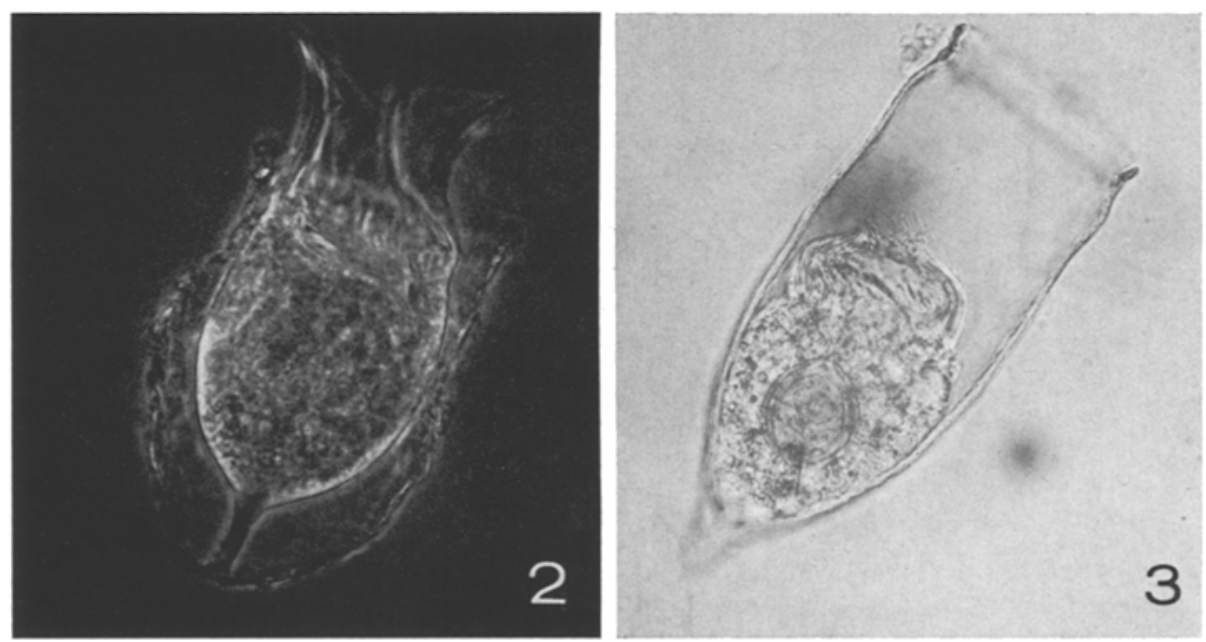

Fig. 2: Tintinnopsis lobmanni. (Cultured, after Gold 1969a)

Fig. 3: Favella campanula. (Cultured, after Golo 1969a, b) 


\section{Tintinnida}

Tintinnopsis beroidea (Fig. 7, agnotobiotic, phagotrophic). Abundance of this species in plankton was variable, ranging from sparse to their having been the dominant infusoria at times. Though agnotobiotic, the principal foods that sustain them are deliberately added at each new transfer. The methods used to maintain them are the same as those described for T. tubulosa (GoLD 1968): final cell yields in excess of $100 \mathrm{cell} / \mathrm{s} / \mathrm{ml}$ have been obtained.

Several strains have been isolated for the purpose of identifying mating types, to prolong longevity through conjugation. Conjugation is a rare phenomenon in local plankton, observed by this investigator only a few times. Attempts to grow clones
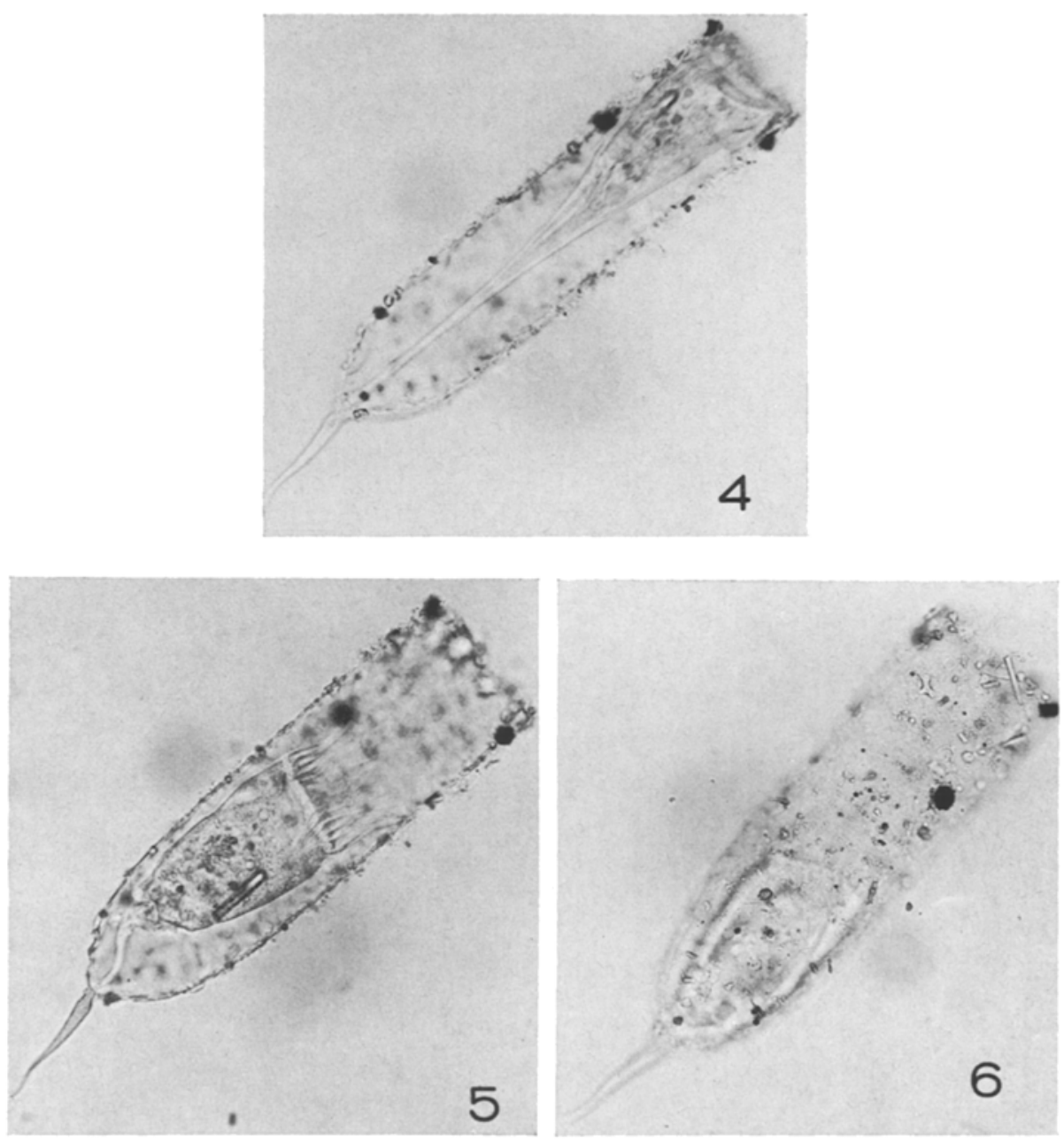

Fig. 4-6: Tintinnopsis platensis shown in various stages of contraction 
from exconjugants were unsuccessful at the time the observations were made. (The difficulty in establishing clones is exemplified by the fact that of 20 clones of $T$. beroida started, only 2 have reproduced. These were from cultures maintained in vitro for 6 months, and presumably were already adapted to our culture conditions.)

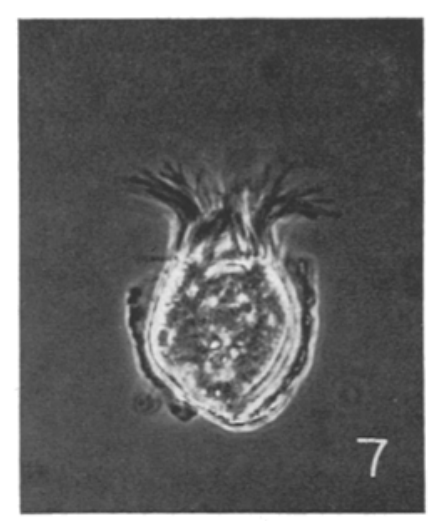

Fig. 7: Tintinnopsis beroidea. (In culture)

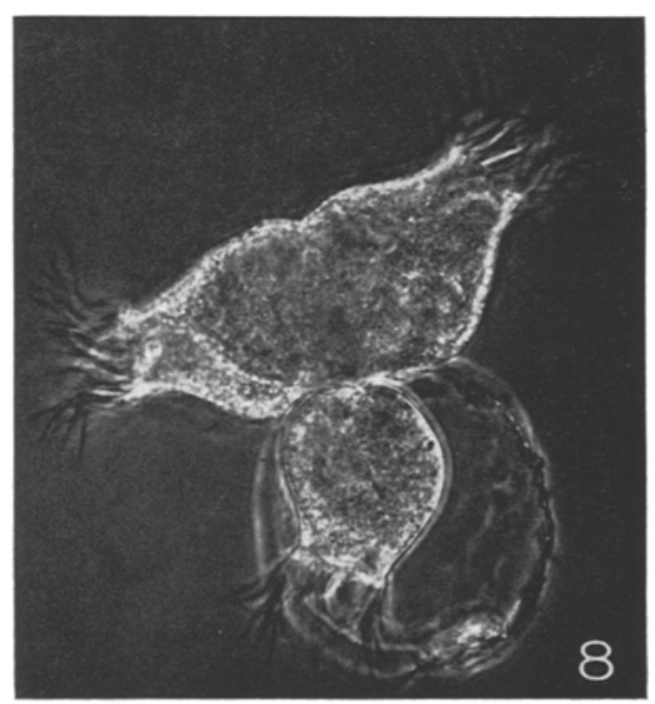

Fig. 8: Tintinnopsis beroidea. (In culture.) Abnormal development apparently the result of culturing conditions. (See text for explanation)

Metacylis sp. (Fig. 9). This species is not presently in culture. Initially it exhibited the rapid feeding and division rates that are associated with the Tintinnida as a group. Cells were pipetted from a plankton sample directly into medium $\mathrm{D}$, and fed the $\mu$-flagellates Isocbrysis galbana, Rhodomonas lens, and Platymonas sp. along 
with the dinoflagellates Glenodinium foleaceum and Ampbidium sp. After overnight growth at $20^{\circ} \mathrm{C}$ the tintinnids had the characteristic coloration that resulted from ingestion of dinoflagellates; there was a noticeable reduction in flagellate number. Known numbers of tintinnids were then pipetted into fresh medium $D$ and fed only

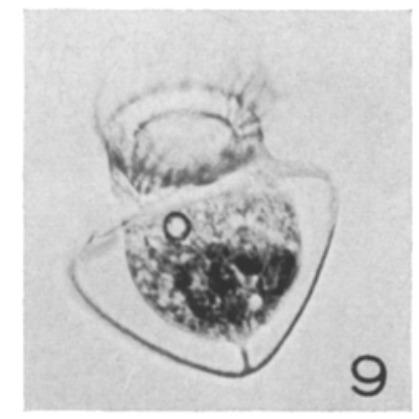

Fig. 9: Metacylis sp.

Glenodinium and Ampbidinium. After approximately $18 \mathrm{hrs}$, tintinnid numbers were again determined and generation times $\left(\mathrm{t}_{2}\right)$ calculated $\left(\mathrm{t}_{2}=0.69 / \mathrm{k} ; \mathrm{k}=\mathrm{dN} / \mathrm{Ndt}\right.$ ). The calculated generation time of $26 \mathrm{hr}$ compares favorably with generation times of other ciliates grown on algae (PAviovsKayA 1969). The rapid generation time was not maintained, however, for the next series of counts made after 72 hrs showed that cell number had markedly decreased.

\section{Dinoflagellates}

Cryptothecodinium cohnii (Synonym: Gyrodinium cohnii; axenic, osmotrophic). Isolated from warmer waters of Puerto Rico in 1961, this organism is extremely useful where large numbers of cells are needed, e. g. for biochemical purposes such as enzyme studies and in vitamin bioassays (Gold et al. 1966). Though it is not a preferred food for Tintinnida, its potential as a food for invertebrate and fish larvae has not yet been evaluated. If nutritionally adequate and non-toxic, such an organism would be highly useful as a food because of its extremely fast growth rate and relatively simple nutritional requirements. At optimum temperature and non-limiting nutrients $2 \times 10^{3}$ cells $/ \mathrm{mm}^{3}$ can be obtained within 4 days (GOLD \& BAREN 1966). KELLER et al. (1968) recently prepared solid media to facilitate long-term maintenance of this species.

Noctiluca scintillans (axenic, osmotrophic/phagotrophic). This dinoflagellate is not considered a resident of our local waters. It was collected on one occasion in November, 1966 when, as a result of extremely high tides, large numbers were found inshore. It was isolated by allowing the cells to rise in a 1 liter cylinder filled with sea water, then by pipet, skimming off the top layer of water containing the flagellates and inoculating them into sterile sea water. Initially, Noctiluca was fed a mixture of phytoflagellates, but later this was changed to a single Platymonas species that was axenic. 
The purification of Noctiluca and its nutritional requirements will be discussed in a separate communication. Miss M. P. McGINN, presently engaged in this research for a Ph. D. dissertation, purified it by washing and use of antibiotics, followed by growth in darkness in a heat-sterilized, organically enriched medium (McGINN \& Gold 1969).

It has retained its characteristic structure and modes of division, and remains brightly luminescent. This organism now has potential for luminescent assays, comparative bio-luminescent systems analyses, and life-cycle studies.

\section{Choanoflagellates}

Diaphanoeca grandis and Acanthoecopsis sp. (bacterized, osmotrophic). Gold (1968) said that Diaphanoeca may be useful as a food for Tintinnopsis and that fragments of the lorica may be incorporated into tintinnid loricas. This hypothesis can now be tested since application of bacteriostatic concentrations of antibiotics now permits growth of both species in highly enriched media yielding numerous choanoflagellates. In addition, sufficient material will now be available for analysis of the way the choanoflagellate lorica is made.

\section{DISCUSSION}

Factors that contributed to the neglect of marine heterotrophic protozoa were their small size and the lack of fixatives that preserved structural detail, making identification and enumeration difficult or impossible. Ways to solve this problem lie in: (1) preparation of better fixatives and use of more meaningful taxonomic criteria (Goud 1969a); (2) through cultivation, to identify the ecologically important groups through their food requirements and nutritional peculiarities.

Provasoli \& Pintner (1953) pointed out the ecologic significance of in vitro analyses of growth requirements of plankton organisms. Their premise was that if a nutrient was required in vitro, then its physiological equivalent or the nutrient itself must have been present in the environment from which that organism was selected. Extrapolation of this idea to metazoa gave insight into reasons why some foods were good, while others were inadequate (SHrraishi \& Provasoli 1959). Similar experiments are needed for phagotrophic protozoa.

The ecologic benefits to be derived from in vitro analyses of nutritional requirements is only one of the reasons for studying heterotrophs; there is much that can be learned about populations from predator/prey experiments. STACHURSKA (1969) employed Dileptus (predator) and Colpidium (prey) and observed that abundance of food influenced the rate of doubling of predators. Above-optimum concentrations of food prolonged doubling time. Empirically it was found that relatively sparse amounts of food were generally better than overabundance for obtaining high cell yields of Tintinnida (GOLD, unpublished observations), suggesting that there is a similar growth-retarding effect of supra-optimal food concentrations. 
The availability of diverse organisms that can be tested for rearing larvae must also be considered. The use of heterotrophic organisms as foods for culturing larval invertebrates and fish has not been exploited. Still another application is the use of holozoic organisms in bioassays. Such organisms should be particularly useful for determinations where it is desirable to differentiate between particulate or bound, and dissolved growth substances.

\section{SUMMARY}

1. Five species of heterotrophic Protozoa are presently under investigation in this laboratory. They are: the tintinnid, Tintinnopsis beroidea, 2 species of dinoflagellate, Cryptothecodinium cohnii and Noctiluca scintillans, and the choanoflagellates Diaphanoeca grandis and Acanthoecopsis sp.

2. Their nutritional status and some potential applications are discussed, along with some observations on other tintinnids previously cultured.

Acknowledgements. I am grateful to Miss L. M. Blackmon and Mr. T. J. Smith for valuable technical assistance.

\section{LITERATURE CITED}

Gold, K., 1968. Some observations on the biology of Tintinnopsis sp. J. Protozool. 15, 193-194.

- 1969a. The Preservation of Tintinnids. J. Protozool. 16, 126-128.

-- 1969b. Tintinnida: Feeding experiments and lorica development. J. Protozool. 16, 507-509.

- \& Baren, C. F., 1966. Growth requirements of Gyrodinium cohnii. J. Protozool. 13, 255-257.

- Roels, O. A. \& Bank, H., 1966. Temperature dependent destruction of thiamine in sea water. Limnol. Oceanogr. 11, 410-413.

Keller, S. E., Hutner, S. H. \& Keller, D. E., 1968. Rearing the colorless marine dinoflagellate Cryptothecodinium cohnii for use as a biochemical tool. J. Protozool. 15, 792-795.

Kudo, R. R., 1966. Protozoology. C. C. Thomas, Springfield, Ill., 1174 pp.

Lee, J. J., McEnery, M., Pierce, S., Freudenthal, H. D. \& Muller, W. A., 1966. Tracer experiments in feeding littoral foraminifera. J. Protozool. 13, 659-670.

McGinn, M. P. \& Gold, K., 1969. Axenic cultivation of Noctiluca scintillans. J. Protozool. 16 (Suppl.).

Pavlovskaya, T. W., 1969. Experiments on algal nutrition of some Black Sea ciliates. Int. Congr. Protozool. 3 (Leningrad), 174.

Provasoli, L. \& Pintner, I. J., 1953. Ecological implications of in vitro nutritional requirements of algal flagellates. Ann. N.Y. Acad. Sci. 56, 839-851.

Shiraishr, K. \& Provasoli, L., 1959. Growth factors as supplements to inadequate algal foods for Tigriopus japonicus. Toboku J. agric. Res. 10, 89-96.

Stachurska, T., 1969. Elements of energy balance of Dileptus cygnus Calp. et Lach. Int. Congr. Protozool. 3 (Leningrad), 156.

Author's address: Dr. K. Gol.

Osborn Laboratories of Marine Sciences

New York Aquarium

Boardwalk \& W. 8th Street

Brooklyn, N.Y. 11224, USA 